\title{
Spatial patterns and impacts of soil conservation service in China
}

\author{
Enming Rao ${ }^{a}$, Zhiyun Ouyang ${ }^{a}$, Xinxiao Yu ${ }^{b}$, Yi Xiao ${ }^{\text {a,* }}$ \\ a State Key Laboratory of Urban and Regional Ecology, Research Center for Eco-Environmental Sciences, Chinese Academy of Sciences, Beijing 100085, China \\ b Key Laboratory of Soil and Water Conservation and Desertification Combating of the Ministry of Education, School of Soil and Water Conservation, Beijing Forestry University, \\ Beijing 100083, China
}

\section{A R T I C L E I N F O}

\section{Article history:}

Received 21 June 2013

Received in revised form 25 October 2013

Accepted 26 October 2013

Available online 5 November 2013

\section{Keywords:}

Soil conservation

Ecosystem services

Spatial pattern

Impacts

Universal Soil Loss Equation

China

\begin{abstract}
A B S T R A C T
We quantified the soil conservation service of ecosystems in China on a GIS platform using the Universal Soil Loss Equation (USLE) and revealed spatial patterns and impacts of this service. The results showed that the total amount and mean capacity of soil conservation service in China were 214.64 billion $\mathrm{t} \mathrm{a}^{-1}$ and $224.42 \mathrm{tha}^{-1} \mathrm{a}^{-1}$, respectively. South-east China generally displayed a much higher capacity than the north-west, and ecosystems with a capacity of $>1000 \mathrm{t} \mathrm{ha}^{-1} \mathrm{a}^{-1}$ were primarily located in mountain areas, including the Tsinling, Nanling, and Wuyi Mountains. Through comparisons, ecosystems located in the provinces of Fujian, Guangxi, Zhejiang, those in the basins of south-eastern rivers, the Pearl River, and the Yangtze River, and those at elevations of 200-1000 m all performed much better than others, from the erosion control perspective. As for the impacts, the spatial characteristics of soil conservation service in China were primarily controlled by climate and terrain at the national scale. In addition, population growth might not affect the soil conservation service directly, whereas land reclamation could impair this service and subsequently exacerbate soil erosion. Finally, the results of this study could contribute to soil erosion control and ecosystem protection in China.
\end{abstract}

(C) 2013 Elsevier B.V. All rights reserved.

\section{Introduction}

Ecosystem services are the foundation on which human survival and development depend (Ouyang and Zheng, 2009). Soil conservation (SC), which is a fundamental regulating service, is defined as the reduction of soil erosion (we focus on water erosion in this study) by ecosystems through their structures and processes (Ausseil et al., 2013). It is reported that $\sim 60 \%$ ( 15 out of 24 ) of the ecosystem services evaluated worldwide are being degraded, including SC (MEA, 2005), which will undoubtedly exacerbate the serious soil erosion problems.

In China, the degradation of SC has resulted in soil erosion becoming one of the most prominent national ecological problems. Nearly one-third of China's land area is suffering from soil erosion, resulting in an economic loss equivalent to $3.5 \%$ of total GDP (Chen, 2012). In addition, soil erosion can lead to land degradation and lake/reservoir siltation (Canton et al., 2011), thus threaten ecological security, food security, and flood protection. Accordingly, assessment and enhancement of SC service in China will be critical to controlling soil erosion and ensuring ecological security.

The Universal Soil Loss Equation (USLE) is an empirical model established by the U.S. Department of Agriculture for predicting soil erosion rates in the USA (Wischmeier and Smith, 1978). It has been

\footnotetext{
* Corresponding author. Tel.: +861062849335.

E-mail address: xiaoyi@rcees.ac.cn (Y. Xiao).
}

widely applied around the world owing to its simple form and ease of use. Especially, when combined with GIS, it is endowed with the capability of spatial analysis and large-scale applicability (Van der Knijff et al., 2000; Pham et al., 2001; Yang et al., 2003; Zhao et al., 2009). Besides its use in soil erosion research, the USLE has been successfully embedded in ecosystem service models, such as InVEST (Tallis et al., 2010), for evaluation of SC service (Nelson et al., 2009; Rife, 2010; Bai et al., 2011; Ren et al., 2011). Parameter localization, which determines the performance of empirical models to some extent, is considered to be a premise though. In this study, we quantified the SC service of ecosystems in China at the national scale on a GIS platform using the USLE model and new achievements in parameters to reveal the spatial patterns and impacts of this service. The results of this study will contribute to soil erosion control and ecosystem protection in China.

\section{Materials and methods}

\subsection{Model description}

The SC of ecosystems can be described as soil erosion prevention (Ausseil et al., 2013), which is the difference between potential and actual soil erosion, with the USLE model being used. The flow chart for SC assessment and analyses is shown in Fig. 1.

The models are presented as follows:

Potential soil erosion : $S E_{\mathrm{p}}=R \times K \times L S$ 


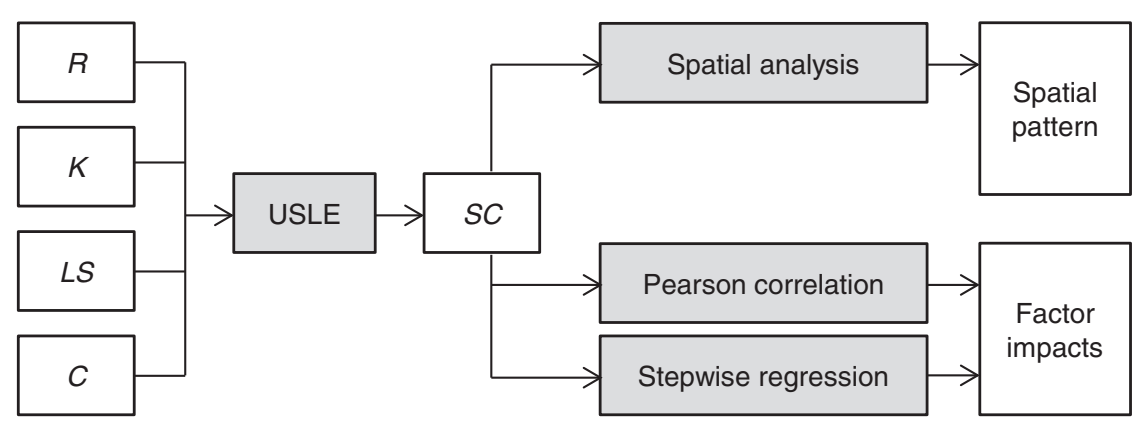

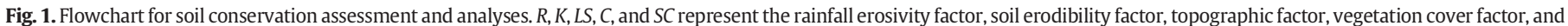
soil conservation capacity, respectively.

Actual soil erosion : $S E_{\mathrm{a}}=R \times K \times L S \times C$

Soil conservation : $S C=R \times K \times L S \times(1-C)$

where, $S E_{\mathrm{p}}$ and $S E_{\mathrm{a}}$ denote the potential and actual soil erosion rates; $S C$ is the soil conservation capacity; $R$ is the rainfall erosivity factor; $K$ is the soil erodibility factor; $L S$ is the topographic factor; and $C$ is the vegetation cover factor, which refers to the protection of soil by ecosystems in this study.

\subsection{Parameters}

\subsubsection{Rainfall erosivity factor $(R)$}

Rainfall erosivity, which describes the potential of rainstorms to cause soil erosion, is determined by rainfall kinetic energy and rainfall intensity (Wischmeier and Smith, 1978; Zhang et al., 2002). We adopted mean annual rainfall erosivity at 603 weather stations nationwide from 1981 to 2010 (Table 1), which was calculated using the Daily Rainfall Erosivity model (SCO, 2010), the latest progress in rainfall erosivity research in China. Interpolation using the Kriging method was employed then to obtain a raster layer of the $R$ factor (spatial resolution of $90 \mathrm{~m}$ ).

The Daily Rainfall Erosivity model (SCO, 2010) can be described as:

$\bar{R}=\sum_{k=1}^{24} \bar{R}_{k}$

$\bar{R}_{k}=\frac{1}{N} \sum_{i=1}^{N}\left(\alpha \sum_{j=1}^{m} P_{\mathrm{d} i j}^{\beta}\right)$

$\alpha=21.239 \beta^{-7.3967}$

$\beta=0.6243+\frac{27.346}{\bar{P}_{\mathrm{d}}}$

$\bar{P}_{\mathrm{d}}=\frac{1}{n} \sum_{l=1}^{n} P_{\mathrm{d} l}$

Table 1

Principal data sources.

\begin{tabular}{lll}
\hline Data name & Data resolution & Data source \\
\hline SRTM digital elevation model & $90 \mathrm{~m}$ & $\begin{array}{l}\text { International scientific data } \\
\text { service platform }\end{array}$ \\
Soil map & $1: 1,000,000$ & $\begin{array}{l}\text { Chinese Academy of Sciences } \\
\text { Chinese Academy of Sciences } \\
\text { Ecosystem map }\end{array}$ \\
NOAA-AVHRR-NDVI & $90 \mathrm{~m}$ & $\begin{array}{l}\text { Thematic database for } \\
\text { human-earth system } \\
\text { Beijing Normal University }\end{array}$ \\
Mean annual rainfall erosivity & 603 points & Statistical Yearbook 2009 \\
Population & Counties & Statistical Yearbook 2009 \\
Cropland percentage & Counties &
\end{tabular}

where, $\bar{R}$ is the mean annual rainfall erosivity (MJ mm ha ${ }^{-1} \mathrm{~h}^{-1} \mathrm{a}^{-1}$ ); $\bar{R}_{k}$ is the mean rainfall erosivity in the $k$-th half month; $P_{\mathrm{d} i j}$ is the daily precipitation $(\mathrm{mm})$ on the $j$-th day of the $k$-th half month in the $i$-th year; $\alpha$ and $\beta$ account for regression coefficients; $\bar{P}_{\mathrm{d}}$ is the mean daily precipitation; $P_{\mathrm{d} l}$ is the daily precipitation on the $l$-th day in the study period; $k$ represents the order of 24 half months for a year $(k=1,2, \ldots, 24)$; $i$ represents the order of years in the study period $(i=1,2, \ldots, \mathrm{N})$; $j$ represents the order of days in the $k$-th half month of the $i$-th year $(j=1,2, \ldots, \mathrm{m})$; and $l$ represents the order of days in the entire study period $(l=1,2, \ldots, \mathrm{n})$. Note that only days with precipitation greater than or equal to $12 \mathrm{~mm}$ are included.

\subsubsection{Soil erodibility factor $(K)$}

Soil erodibility describes the susceptibility of soil particles to detachment and movement by water, and reflects the sensitivity of soils to erosion (Zhang et al., 2007, 2008). In this study, we used the formula in Erosion/Productivity Impact Calculator (EPIC) for calculation and the research conducted by Zhang et al. (2008) for revision, making it applicable to the properties of soils in China.

$$
\begin{aligned}
K_{\mathrm{EPIC}}= & \left\{0.2+0.3 \exp \left[-0.0256 m_{\text {sand }}\left(1-m_{\text {silt }} / 100\right)\right]\right\} \\
& \times\left[m_{\text {silt }} /\left(m_{\text {clay }}+m_{\text {silt }}\right)\right]^{0.3} \\
& \times\{1-0.25 \operatorname{org} C /[\operatorname{org} C+\exp (3.72-2.95 \operatorname{org} C)]\} \\
& \times\left\{1-0.7\left(1-m_{\text {sand }} / 100\right) /\left\{\left(1-m_{\text {sand }} / 100\right)\right.\right. \\
& \left.\left.+\exp \left[-5.51+22.9\left(1-m_{\text {sand }} / 100\right)\right]\right\}\right\} \\
K=(- & \left.0.01383+0.51575 K_{\text {EPIC }}\right) \times 0.1317
\end{aligned}
$$

where, $K_{\mathrm{EPIC}}$ and $K$ are the soil erodibility factor ( $\mathrm{t}$ ha h ha ${ }^{-1} \mathrm{MJ}^{-1} \mathrm{~mm}^{-1}$ ) before and after revision, respectively; and $m_{\text {sand }}, m_{\text {silt }}, m_{\text {clay, }}$ and $\operatorname{org} C$ are the mass percentages of sand $(0.02-2 \mathrm{~mm})$, silt $(0.002-0.02 \mathrm{~mm})$, clay $(<0.002 \mathrm{~mm})$, and organic carbon, respectively. The soil properties were derived for each $90 \times 90 \mathrm{~m}$ cell from the 1:1,000,000 soil map (Table 1).

\subsubsection{Topographic factor $(L S)$}

The topographic factor reflects the impact of slope length and steepness on soil erosion (Wischmeier and Smith, 1978). Although the exact relationship remains uncertain, we assumed that a greater flow accumulation and a faster runoff velocity were, respectively, associated with a longer slope length and steeper slope, and that the erosion rate would stop increasing when the slope reached a certain threshold (Wang and Jiao, 1996). Accordingly, we made some revisions in the calculation based on previous studies (McCool et al., 1993; Liu et al., 1994; Van Remortel et al., 2001), with gentle slopes and steep slopes being differentiated.

$L=(\lambda / 22.13)^{m}$ 
$m=\beta /(1+\beta)$

$\beta=(\sin \theta / 0.089) /\left[3.0 \times(\sin \theta)^{0.8}+0.56\right]$

$S=\left\{\begin{array}{l}10.8 \sin \theta+0.03 \quad \theta<5.14^{\circ} \\ 16.8 \sin \theta-0.5 \quad 5.14^{\circ} \leq \theta<10.20^{\circ} \\ 21.91 \sin \theta-0.96 \quad 10.20^{\circ} \leq \theta<28.81^{\circ} \\ 9.5988 \quad \theta>28.81^{\circ}\end{array}\right.$

where $L$ is the slope length factor; $S$ is the slope steepness factor; $m$ is the slope length index; $\theta$ is slope gradient $\left({ }^{\circ}\right)$; and $\lambda$ is slope length (m). We computed the morphometric parameters from the 90-m SRTM digital elevation model (DEM; Table 1).

\subsubsection{Vegetation cover factor $(C)$}

Vegetation plays a significant part in controlling soil erosion (Collins et al., 2004; Zhou et al., 2006). The vegetation cover factor is critical to soil and water conservation, owing to its high sensitivity to natural and anthropogenic activities (Wang et al., 2001; Ma et al., 2012). Here, the value of the $C$ factor was primarily obtained by referring to previous studies, with a smaller value linking to better controlling effect. For forests, shrubs, and grasslands, a look-up table (Table 2) that considered both the type and coverage of ecosystems was employed (Wei et al., 2002). For farmlands (except paddy lands), the model established by Liu et al. (1999) was applied. While for wetlands (including paddy lands, a type of farmland), cities, and bare lands (e.g., deserts, lichens), values of $0,0.01$, and 0.7 were assigned, respectively, based on the parameters used in N-SPECT (Carter and Eslinger, 2004).

The $C$ factor model for farmlands (Liu et al., 1999) can be described as:

$C=0.221-0.595 \log c$

where, $C$ is the vegetation cover factor of farmland; and $c$ is the vegetation fraction in decimal format, which was estimated from NDVI (Table 1) using the dimidiate pixel model (Li et al., 2004).

\subsection{Data analyses}

\subsubsection{Spatial analyses}

Spatial Analyst tools in ArcGIS were employed to reveal the spatial distribution of SC service, with different provinces, primary river basins, and altitudes considered. The mean capacities and total amounts of SC service in corresponding units were consequently calculated.

\subsubsection{Correlation and regression}

For the purpose of exploring the relationship between SC service and soil erosion risk, we performed Pearson correlations using SC capacities (SC; Eq. (3)) and potential soil erosion rates ( $S E_{\mathrm{p}}$; Eq. (1)). We also employed a stepwise regression between $S C$ and impacts (climate, soil, terrain, and vegetation, represented by the $R, K, L S$, and $C$ factors, respectively) to reveal their relative contribution in influencing the spatial characteristics of SC service.

To discuss the influence of human activities on SC service, we adopted a partial correlation between SC and anthropogenic factors (population growth and land reclamation, represented by population

Table 2

C factor values for various ecosystems (after Wei et al., 2002).

\begin{tabular}{lllllll}
\hline \multirow{2}{*}{ Ecosystem types } & \multicolumn{7}{l}{ Vegetation fraction (\%) } \\
\cline { 2 - 7 } & $<10$ & $10-30$ & $30-50$ & $50-70$ & $70-90$ & $>90$ \\
\hline Forests & 0.10 & 0.08 & 0.06 & 0.02 & 0.004 & 0.001 \\
Shrubs & 0.40 & 0.22 & 0.14 & 0.085 & 0.040 & 0.011 \\
Grasslands & 0.45 & 0.24 & 0.15 & 0.09 & 0.043 & 0.011 \\
\hline
\end{tabular}

density $(P D)$ and areal cropland percentage $(C P)$, respectively), since $P D$ and $C P$ were significantly correlated $(r=0.437, n=2139$, $p<0.001)$. All statistical analyses mentioned in this section were performed at the county level.

\subsection{Data sources and processing}

The data which were used in our study could be simply grouped into spatial data and statistics. Some details concerning the data are listed in Table 1. In addition, ecosystems were classified into seven categories in this study, including forests, shrubs, grasslands, farmlands, wetlands, cities and bare lands. The calculations and analyses were implemented using ArcGIS 9.3, SPSS 17.0, and SigmaPlot 11.0.

\section{Results}

\subsection{Model validation}

To assure the model's regional applicability, we validated the USLE model with soil erosion rates estimated from observed data for seven major river basins in China (MWR et al., 2010). The simulations (USLE) of soil erosion rates agreed well with the corresponding estimates ( $r=0.821, n=7, p<0.05$; Fig. 2). Therefore, we could confirm that USLE and its parameters used here were able to simulate general soil erosion conditions in China. Indirectly, the model of the SC service could also be considered reasonable.

\subsection{Spatial characteristics of SC}

The potential and actual annual soil erosion was calculated to be 229.75 billion $t$ and 15.11 billion $t$, respectively. Thus, the total amount of soil retained was 214.64 billion $\mathrm{t} \mathrm{a}^{-1}$, with a mean capacity of $224.42 \mathrm{tha}^{-1} \mathrm{a}^{-1}$. The SC service displayed great heterogeneity in terms of its spatial distribution, with south-east China generally performing much better than the north-west (Fig. 3). Ecosystems with a great capacity $\left(>1000 \mathrm{t} \mathrm{ha}^{-1} \mathrm{a}^{-1}\right.$ ) were primarily located in the Tsinling Mountains, the hills surrounding the Sichuan Basin, the Nanling Mountains, the Wuyi Mountains, and the mountain areas of southern Anhui Province and central Hainan Province.

\subsubsection{Regional distributions of SC}

Comparisons among provinces (Fig. 4A) indicated that Fujian Province had the highest SC capacity, followed by Guangxi, Zhejiang, Chongqing, and Guangdong. With regard to the total amount, ecosystems in

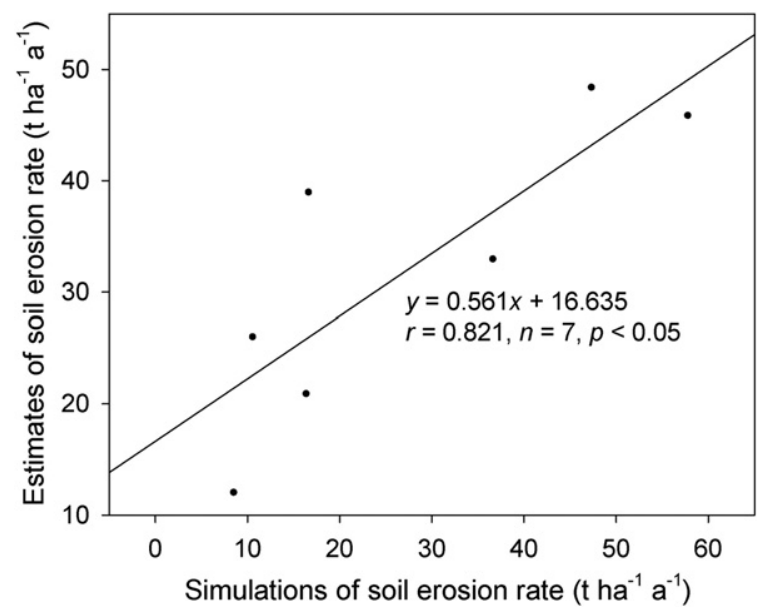

Fig. 2. Validation of the USLE model. The simulations (USLE) and observations (MWR et al., 2010) of mean annual soil erosion rates correspond to specific parts of river basins, including those of the Songhua, Haihe, Liaohe, Pearl, Huaihe, Yangtze, and Yellow. 


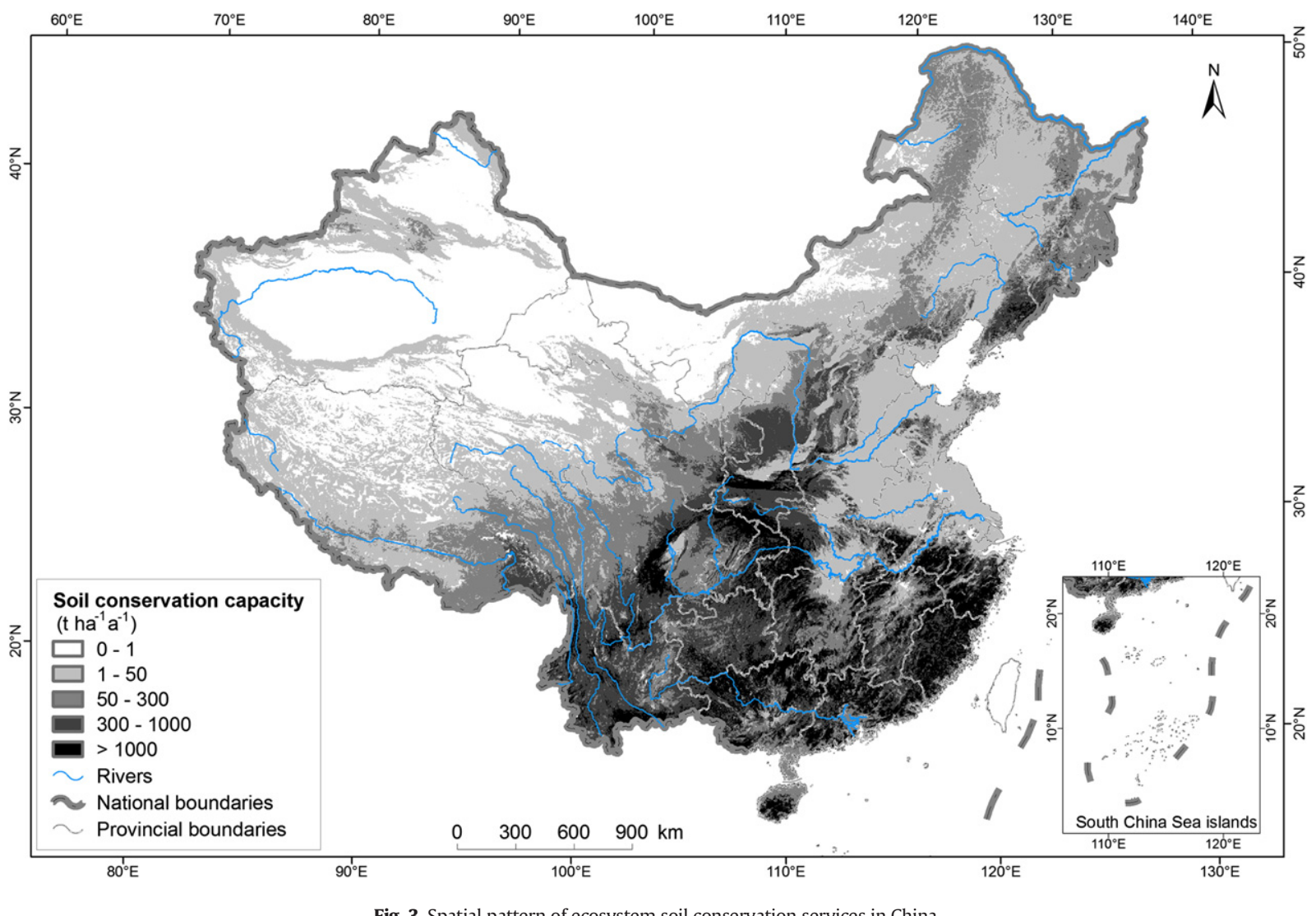

Fig. 3. Spatial pattern of ecosystem soil conservation services in China.

Yunnan, Guangxi, and Sichuan contributed most, accounting for $11.51 \%$, $10.89 \%$, and $10.23 \%$, respectively, of the total. The accumulative proportion would be greater than four-fifths when the provinces of Hunan, Fujian, Guizhou, Shannxi, Jiangxi, Hubei, Zhejiang, and Chongqing were added, while the sum of area ratio was only about one-fourth.

Comparisons among primary river basins (Fig. 4B) showed that the basins of the south-eastern rivers, the Pearl River Basin, and the Yangtze River Basin had the highest SC capacities, and the Yangtze River Basin had the largest amount, accounting for $42.24 \%$ of the total. What followed was the Pearl River Basin, accounting for $22.70 \%$ of the total.

Comparisons among altitudes (Fig. 4C) showed that ecosystems with an elevation of 200-500 m displayed the highest SC capacities, followed by those with an elevation of $500-1000 \mathrm{~m}$. With regard to quantities, ecosystems located at elevations of 200-500, 500-1000, and $1000-2000 \mathrm{~m}$ retained much more soil than others, with those located at $500-1000 \mathrm{~m}$ preserving most ( $30 \%$ of the total).

\subsubsection{Relationship between SC and soil erosion risk}

The SC capacity displayed a significant positive correlation ( $r=0.998, n=2273, p<0.001$; Fig. 5 ) with potential soil erosion rate, which was determined by climate, soil, and terrain. Where the risk of soil erosion is high, the capacity of soil conservation for an ecosystem is considerable.

\subsection{Impacts of influencing factors on $S C$}

The spatial characteristics of SC service are formed by the interactions between influencing factors. The stepwise regression indicated that, the $R$ and $L S$ factors could explain most variance in $S C$, with the variance contribution $(V C)$ reaching $35.7 \%$ and $36.3 \%$, respectively. The $V C$ values of the $K$ and $C$ factors were relatively small.

The partial correlation between $S C$ and $P D$, with $C P$ controlled, was not statistically significant. In contrast, $S C$ was negatively correlated with $C P(r=-0.392, n=2139, p<0.001)$, with $P D$ controlled. This negative correlation could also be observed from the scatter plot based on the unit of county (Fig. 6).

\section{Discussion}

In the process of parameter localization for the USLE, we analyzed relevant progress in domestic research first, and calculated soil erosion rates as well as SC capacities using recent achievements on the parameters. Through comparison with the estimates of soil erosion rates in river basins, the USLE model and the parameters used herein proved capable of realistically simulating the soil erosion situation in China, thus rendering a satisfactory accuracy to the assessment of SC service. Moreover, a spatial resolution of $90 \mathrm{~m}$ was used here, which was the highest up to now for such a large scale, so as to capture the spatial heterogeneity of environmental variables more effectively.

In this study, the actual amount of soil erosion in China was estimated at 15.11 billion $\mathrm{t} \mathrm{a}^{-1}$, more than the mean measurement of 5 billion $\mathrm{t}$ (Peng, 2001). The primary reason for the difference is that the output of the USLE is the amount of soil eroded or moved (Yang et al., 2003; Rife, 2010), while the measurement usually refers to the sediment yield at river outlets. They are not equivalent concepts and therefore not directly comparable. The total amount of SC, which describes the reduction in soil erosion by ecosystems, was estimated at 214.64 billion $\mathrm{t} \mathrm{a}^{-1}$, with a mean capacity of $224.42 \mathrm{t} \mathrm{ha}^{-1} \mathrm{a}^{-1}$, well matching the SC capacity of forests and grasslands (118.61-445.92 $\left.\mathrm{t} \mathrm{ha}^{-1} \mathrm{a}^{-1}\right)$ that was determined through surveys and syntheses (Ouyang et al., 1999).

The ecosystems' SC service in China was spatially unevenly distributed, due to the vast territory and enormous differences in environmental conditions. Ecosystems located in the provinces of Fujian, Guangxi, Zhejiang, in the basins of south-eastern rivers, the Pearl River, the Yangtze River, and at elevations of 200-1000 m all demonstrated excellent soil erosion control, thus deserving careful protection in the future. Additionally, based on the positive correlation between SC service and soil erosion risk, greater importance should be given to higher erosion 

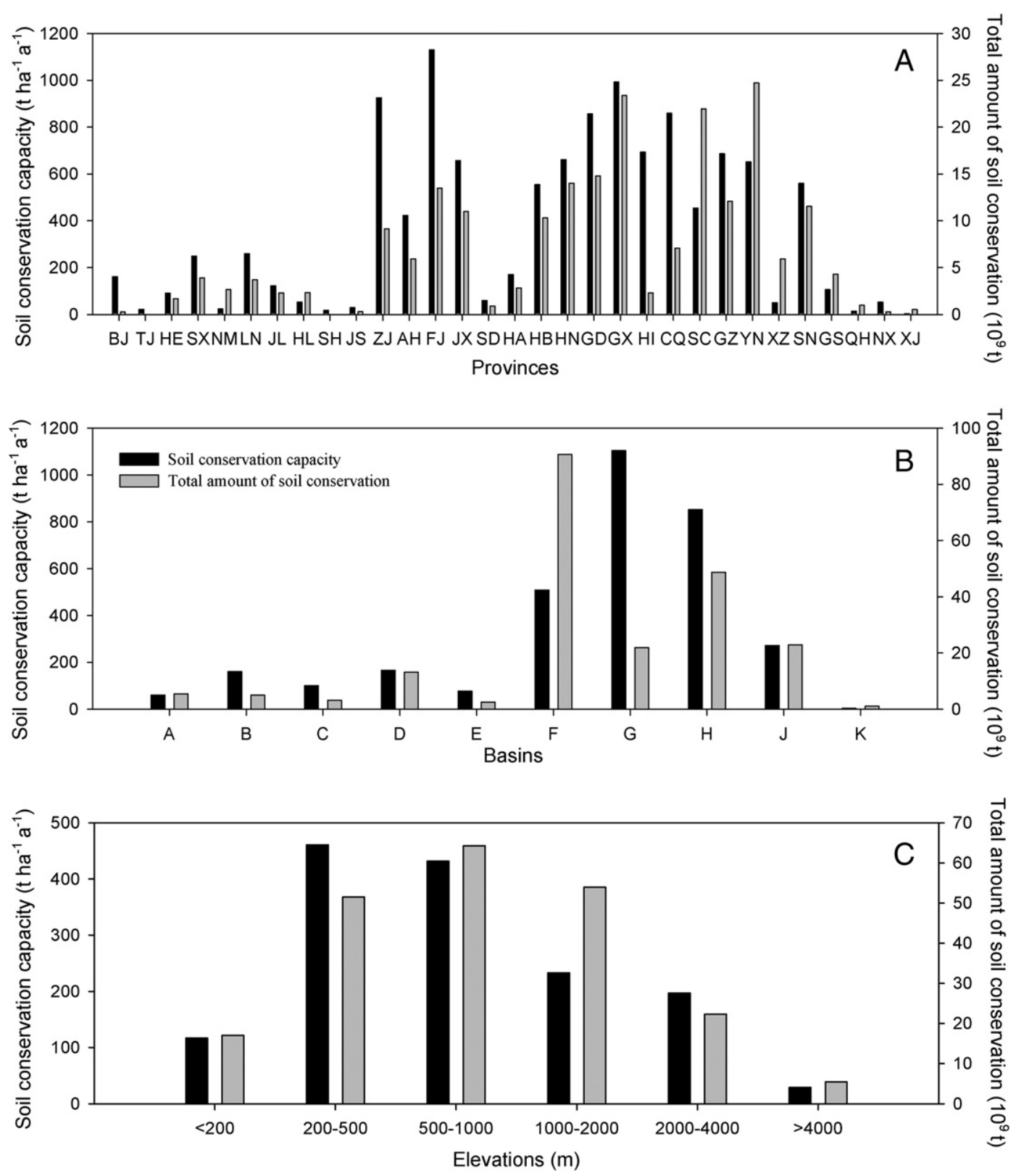

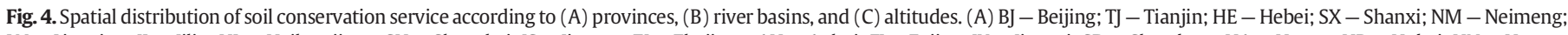

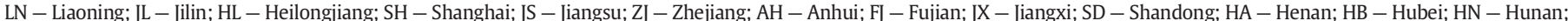

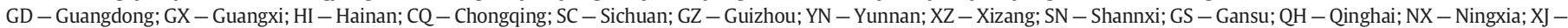

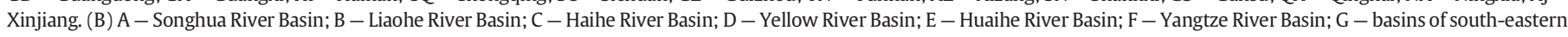
rivers; $\mathrm{H}$ - Pearl River Basin; J - basins of south-western rivers; $\mathrm{K}$ - basins of north-western rivers.

risk areas (Rahman et al., 2009), such as the Loess Plateau and southeastern China, since the state of ecosystems in these areas could be fairly critical to the actual situation of soil erosion.

Overall, south-eastern China displayed a much higher SC capacity than the north-west (Sheng et al., 2010), quite similar to the spatial pattern of precipitation (Wang and Ding, 2008). Ecosystems with a great SC capacity (>1000 tha $\mathrm{t}^{-1} \mathrm{a}^{-1}$ ) were primarily located in mountain areas, such as the Tsinling, Nanling, and Wuyi Mountains, implying a potential influence of topography. Stepwise regression further demonstrated that the spatial patterns of SC service in China were primarily controlled by climate and terrain, while the effects of soil and vegetation were relatively small at the national scale. The probable reason was that the natural patterns of soil and vegetation greatly depended on the climate and terrain at a large scale, and the multicollinearity among factors weakened the contribution of soil and vegetation. At small scales, when climate and terrain were relatively uniform, soil and vegetation probably became dominant factors, just like the situation in the Zhangjiajie National Forest Park, China (Zhao et al., 2009).

Anthropogenic activities, such as population growth and land reclamation, are the main drivers of change in ecosystems and their services (Zheng et al., 2003; Ouyang and Zheng, 2009; Su et al., 2012). The population exerts significant pressure on ecosystems if its size is large and density is high, and agricultural lands have been regarded as major sources of sediment (Pimentel et al., 1995; Lin et al., 2008). A negative partial correlation was found between $S C$ and $C P$, while no significant correlation was found between $S C$ and $P D$. These findings suggest that population growth could not directly influence the SC service, but land reclamation could impair it and intensify soil erosion through changing ecosystem structures and processes (Zheng et al., 2003; Ouyang and Zheng, 2009). A slowdown or reversal of land reclamation would be 


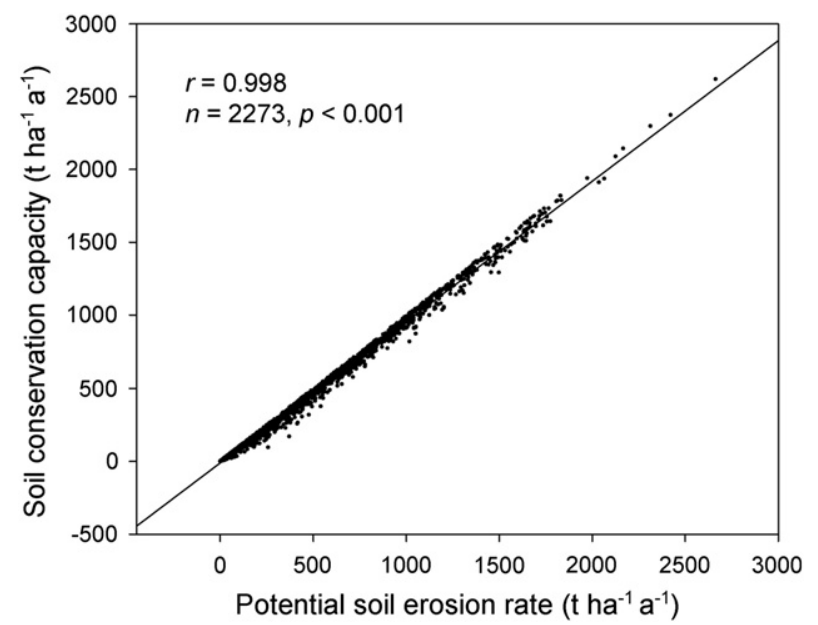

Fig. 5. Relationship between soil conservation service and soil erosion risk. Each dot represents a county. The line represents the fitted curve.

very helpful in soil erosion control in China (Feng et al., 2010; Su and Fu, 2013), which is the principal motivation for the Grain-to-Green and similar projects (Lü et al., 2012).

\section{Conclusions}

Through parameter localization and using high resolution data, a satisfactory overview was obtained in soil erosion and soil conservation in China. The spatial patterns and impacts of soil conservation service, which were significant in soil and water conservation planning, were also discussed using spatial analyses and statistical analyses. The results suggest that:

1) Ecosystems can reduce a huge amount of soil erosion, with a total of 214.64 billion $t$ of soil being conserved annually in China.

2) Soil conservation service displays great spatial heterogeneity, with south-eastern China performing much better than the north-west, and regions with a great capacity primarily located in mountain areas. Specifically, ecosystems located in the provinces of Fujian, Guangxi, Zhejiang, those in the basins of south-eastern rivers, the Pearl River, the Yangtze River, and those at elevations of 200-1000 m demonstrate excellent soil erosion control, thus deserving careful protection in the future.

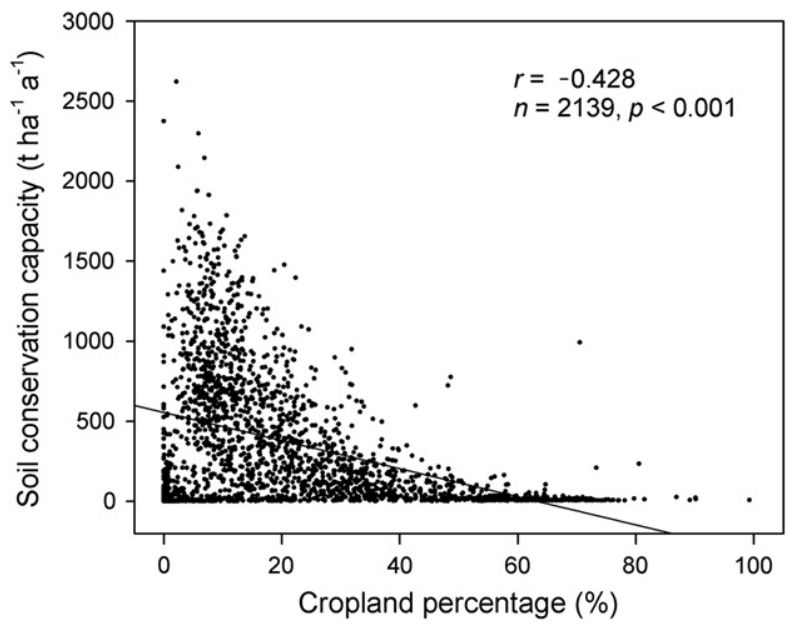

Fig. 6. Relationship between soil conservation service and cropland percentage. Each dot represents a county. The line represents the fitted curve.
3) The spatial characteristics of soil conservation service in China are primarily dominated by climate and terrain at the national scale.

4) Land reclamation can impair soil conservation service and exacerbate soil erosion subsequently.

\section{Acknowledgments}

This research was funded by the National Basic Research Program of China (no. 2009CB421105). Special thanks to Professors Yun Xie, Keli Zhang, and Yongqiu Wu of Beijing Normal University for their immeasurable help with research methods.

\section{References}

Ausseil, A.G.E., Dymond, J.R., Kirschbaum, M.U.F., Andrew, R.M., Parfitt, R.L., 2013. Assessment of multiple ecosystem services in New Zealand at the catchment scale. Environ. Model Softw. 43, 37-48.

Bai, Y., Zhuang, C., Ouyang, Z., Zheng, H., Jiang, B., 2011. Spatial characteristics between biodiversity and ecosystem services in a human-dominated watershed. Ecol. Complex. 8, 177-183.

Canton, Y., Sole-Benet, A., de Vente, J., Boix-Fayos, C., Calvo-Cases, A., Asensio, C., Puigdefabregas, J., 2011. A review of runoff generation and soil erosion across scales in semiarid south-eastern Spain. J. Arid Environ. 75, 1254-1261.

Carter, H.J., Eslinger, D.L., 2004. Nonpoint Source Pollution and Erosion Comparison Tool (N-SPECT) technical guide. NOAA-CSC.

Chen, L., 2012. Implement the central decision and deployment thoroughly, and write a new chapter of soil and water conservation and ecological construction with Chinese characteristics. Conference speech, Ministry of Water Resources of China (http:// www.mwr.gov.cn/slzx/slyw/201202/t20120225_314599.html, as of 31/05/2013, in Chinese).

Collins, D.B.G., Bras, R.L., Tucker, G.E., 2004. Modeling the effects of vegetation-erosion coupling on landscape evolution. J. Geophys. Res. Earth Surf. 109, F03004.

Feng, X.M., Wang, Y.F., Chen, L.D., Fu, B.J., Bai, G.S., 2010. Modeling soil erosion and its response to land-use change in hilly catchments of the Chinese Loess Plateau. Geomorphology 118, 239-248.

Li, M.M. Wu, B.F, Yan, CZ, Zhou, W.F, 2004. Estimation of vegetation fraction in the Upper Basin of Miyun Reservoir by remote sensing. Resour. Sci. 26, 153-159 (in Chinese with English abstract).

Lin, W.T., Tsai, J.S., Lin, C.Y., Huang, P.H., 2008. Assessing reforestation placement and benefit for erosion control: a case study on the Chi-Jia-Wan Stream, Taiwan. Ecol. Model. 211, 444-452.

Liu, B.Y., Nearing, M.A., Risse, L.M., 1994. Slope gradient effects on soil loss for steep slopes. Trans. Am. Soc. Agric. Eng. 37, 1835-1840.

Liu, B.Z., Liu, S.H., Zheng, S.D., 1999. Soil conservation and coefficient of soil conservation of crops. Res. Soil Water Conserv. 6 (2), 32-36 (in Chinese with English abstract).

Lü, Y., Fu, B., Feng, X., Zeng, Y., Liu, Y., Chang, R., Sun, G., Wu, B., 2012. A policy-driven large scale ecological restoration: quantifying ecosystem services changes in the Loess Plateau of China. Plos One 7 (2), e31782. http://dx.doi.org/10.1371/journal.pone.0031782.

Ma, Q., Yu, X.X., Lü, G.A., Liu, Q.J., 2012. The changing relationship between spatial pattern of soil erosion risk and its influencing factors in Yimeng mountainous area, China 1986-2005. Environ. Earth Sci. 66, 1535-1546.

McCool, D.K., George, G.O., Freckleton, M., Douglas, C.L., Papendick, R.I., 1993. Topographic effect on erosion from cropland in the northwestern wheat region. Trans. Am. Soc. Agric. Eng. 36, 1067-1071.

Millennium Ecosystem Assessment (MEA), 2005. Ecosystems and Human Well-being: Synthesis. Island Press, Washington, DC.

Ministry of Water Resources of China (MWR), Chinese Academy of Sciences (CAS), Chinese Academy of Engineering (CAE), 2010. Control of soil erosion and ecological security in China: soil erosion data volume. Control of Soil Erosion and Ecological Security in China.Science Press, Beijing (in Chinese).

Nelson, E., Mendoza, G., Regetz, J., Polasky, S., Tallis, H., Cameron, D.R., Chan, K.M.A., Daily, G.C., Goldstein, J., Kareiva, P.M., Lonsdorf, E., Naidoo, R., Ricketts, T.H., Shaw, M.R., 2009. Modeling multiple ecosystem services, biodiversity conservation, commodity production, and tradeoffs at landscape scales. Front. Ecol. Environ. 7, 4-11.

Ouyang, Z.Y., Zheng, H., 2009. Ecological mechanisms of ecosystem services. Acta Ecol. Sin. 29, 6183-6188 (in Chinese with English abstract).

Ouyang, Z.Y., Wang, X.K., Miao, H., 1999. A primary study on Chinese terrestrial ecosystem services and their ecological-economic values. Acta Ecol. Sin. 19, 607-613 (in Chinese with English abstract)

Peng, K.S., 2001. Situation of Chinese soil erosion and comprehensive counter-measures. J. Guangxi Econ. Manag. Cadre 13 (3), 4-8 (in Chinese with English abstract).

Pham, T.N., Yang, D.W., Kanae, S., Oki, T., Musiake, K., 2001. Application of RUSLE model on global soil erosion estimate. Annu. J. Hydraul. Eng. 45, 811-816.

Pimentel, D., Harvey, C., Resosudarmo, P., Sinclair, K., Kurz, D., McNair, M., Crist, S., Shpritz, L., Fitton, L., Saffouri, R., Blair, R., 1995. Environmental and economic costs of soil erosion and conservation benefits. Science 267, 1117-1123.

Rahman, M.R., Shi, Z.H., Cai, C.F., 2009. Soil erosion hazard evaluation-An integrated use of remote sensing, GIS and statistical approaches with biophysical parameters towards management strategies. Ecol. Model. 220, 1724-1734.

Ren, J., Wang, Y.K., Fu, B., Xu, P., 2011. Soil conservation assessment in the Upper Yangtze River Basin based on the InVEST Model. Water Resource and Environmental Protection (ISWREP), 2011 International Symposium on IEEE, Xi'an, pp. 1833-1836. 
Rife, T.L., 2010. Modeling the value of ecosystem services. Application to Soil Loss in Southeastern Allegheny County.Youngstown State University, USA (Master Thesis).

Sheng, L., Jin, Y., Huang, J.F., 2010. Value estimation of conserving water and soil of ecosystem in China. J. Nat. Resour. 25, 1105-1113 (in Chinese with English abstract).

State Council Office of China (SCO), 2010. Training Manual of the First Nationwide Water Resources Survey: Census of Soil and Water Conservation. China Water Power Press, Beijing (in Chinese).

Su, C.H., Fu, B.J., 2013. Evolution of ecosystem services in the Chinese Loess Plateau under climatic and land use changes. Glob. Planet. Chang. 101, 119-128.

Su, C.H., Fu, B.J., Wei, Y.P., Lü, Y.H., Liu, G.H., Wang, D.L., Mao, K.B., Feng, X.M., 2012. Ecosystem management based on ecosystem services and human activities: a case study in the Yanhe watershed. Sustain. Sci. 7, 17-32.

Tallis, H., Ricketts, T., Nelson, E., Ennaanay, D., Wolny, S., Olwero, N., Vigerstol, K., Pennington, D., Mendoza, G., Aukema, J., Foster, J., Forrest, J., Cameron, D., Arkema, K., Lonsdorf, E., Kennedy, C., 2010. InVEST 1.005 beta User's Guide.The Natural Capital Project, Stanford.

Van der Knijff, J.M., Jones, R.J.A., Montanarella, L., 2000. Soil Erosion Risk Assessment in Europe. European Soil Bureau, European Commission.

Van Remortel, R., Hamilton, M., Hickey, R., 2001. Estimating the LS-factor for RUSLE through iterative slope length processing of digital elevation data within ArcInfo grid. Cartography 30, 27-35.

Wang, Z.Y., Ding, Y.H., 2008. Climatic characteristics of rainy seasons in China. Chin. J. Atmos. Sci. 32 (1), 1-13 (in Chinese with English abstract).

Wang, W.Z., Jiao, J.Y., 1996. Quantitative evaluation of factors influencing soil erosion in China. Bull. Soil Water Conserv. 16 (5), 1-20 (in Chinese with English abstract).
Wang, X.K., Ouyang, Z.Y., Xiao, H., Miao, H., Fu, B.J., 2001. Distribution and division of sensitivity to water-caused soil loss in China. Acta Ecol. Sin. 21, 14-19 (in Chinese with English abstract).

Wei, H.B., Li, R., Yang, Q.K., 2002. Research advances of vegetation effect on soil and wate conservation in China. Acta Phytoecologica Sin. 26, 489-496 (in Chinese with English abstract).

Wischmeier, W.H., Smith, D.D., 1978. Predicting Rainfall Erosion Losses: A Guide to Conservation Planning. U.S. Department of Agriculture, Washington DC

Yang, D.W., Kanae, S., Oki, T., Koike, T., Musiake, K., 2003. Global potential soil erosion with reference to land use and climate changes. Hydrol. Process. 17, 2913-2928.

Zhang, W.B., Xie, Y., Liu, B.Y., 2002. Research evolution of rainfall erosivity. J. Soil Water Conserv. 16 (5), 43-46 (in Chinese with English abstract).

Zhang, K.L., Peng, W.Y., Yang, H.L., 2007. Soil erodibility and its estimation for agricultural soil in China. Acta Pedol. Sin. 44, 7-13 (in Chinese with English abstract).

Zhang, K.L., Shu, A.P., Xu, X.L., Yang, Q.K., Yu, B., 2008. Soil erodibility and its estimation for agricultural soils in China. J. Arid Environ. 72, 1002-1011.

Zhao, T.Q., Yang, B.S., Zheng, H., 2009. Assessment of the erosion control function of forest ecosystems based on GIS: a case study in Zhangjiajie National Forest Park, China. Int J. Sustain. Dev. World Ecol. 16, 356-361.

Zheng, H., Ouyang, Z.Y., Zhao, T.Q., Li, Z.X., Xu, W.H., 2003. The impact of human activities on ecosystem services. J. Nat. Resour. 18, 118-126 (in Chinese with English abstract).

Zhou, Z.C., Shangguan, Z.P., Zhao, D., 2006. Modeling vegetation coverage and soil erosion in the Loess Plateau Area of China. Ecol. Model. 198, 263-268. 